University of Massachusetts Amherst

ScholarWorks@UMass Amherst

Environmental Conservation Faculty Publication

Series

Environmental Conservation

2016

\title{
Quantifying the Human Influence on Fire Ignition Across the Western USA
}

\author{
Emily J. Fusco \\ University of Massachusetts Amherst \\ John T. Abatzoglou \\ University of Idaho \\ Jennifer K. Balch \\ University of Colorado, Boulder \\ John T. Finn \\ University of Massachusetts Amherst \\ Bethany Bradley \\ University of Massachusetts Amherst
}

Follow this and additional works at: https://scholarworks.umass.edu/nrc_faculty_pubs

Part of the Ecology and Evolutionary Biology Commons, and the Environmental Studies Commons

\section{Recommended Citation}

Fusco, Emily J.; Abatzoglou, John T.; Balch, Jennifer K.; Finn, John T.; and Bradley, Bethany, "Quantifying the Human Influence on Fire Ignition Across the Western USA" (2016). Ecological Applications. 383.

https://doi.org/10.1002/eap.1395

This Article is brought to you for free and open access by the Environmental Conservation at ScholarWorks@UMass Amherst. It has been accepted for inclusion in Environmental Conservation Faculty Publication Series by an authorized administrator of ScholarWorks@UMass Amherst. For more information, please contact scholarworks@library.umass.edu. 
Received Date : 22-Nov-2015

Revised Date : 30-Apr-2016

Accepted Date : 31-May-2016

Article type : Articles

FINAL VERSION RECEIVED DATE : 27 June 2016

Running head: Spatial analysis of human fire ignitions

Quantifying the human influence on fire ignition across the western US

Emily J. Fusco ${ }^{1}$, John T. Abatzoglou ${ }^{2}$, Jennifer K. Balch ${ }^{3}$, John T. Finn ${ }^{1,4}$,

$$
\text { Bethany A. Bradley }{ }^{1,4}
$$

${ }^{1}$ Organismic and Evolutionary Biology Program, University of Massachusetts-Amherst

${ }^{2}$ Department of Geography, University of Idaho

${ }^{3}$ Department of Geography, University of Colorado-Boulder

${ }^{4}$ Department of Environmental Conservation, University of Massachusetts-Amherst

\section{Abstract}

Humans have a profound effect on fire regimes by increasing the frequency of ignitions. Although ignition is an integral component of understanding and predicting fire, to date fire models have not been able to isolate the ignition location, leading to inconsistent use of anthropogenic ignition proxies. Here, we identified fire ignitions from the Moderate Resolution Imaging Spectrometer (MODIS) burned area product (2000-2012) to create the

This article has been accepted for publication and undergone full peer review but has not been through the copyediting, typesetting, pagination and proofreading process, which may lead to differences between this version and the Version of Record. Please cite this article as doi: 10.1002/eap.1395

This article is protected by copyright. All rights reserved. 
first remotely sensed, consistently derived, and regionally comprehensive fire ignition data set for the western United States. We quantified the spatial relationships between several anthropogenic land use/disturbance features and ignition for ecoregions within the study area, and used hierarchical partitioning to test how the anthropogenic predictors of fire ignition vary among ecoregions. The degree to which anthropogenic features predicted ignition varied considerably by ecoregion, with the strongest relationships found in the Marine West Coast Forest and North American Desert ecoregions. Similarly, the contribution of individual anthropogenic predictors varied greatly among ecoregions. Railroad corridors and agricultural presence tended to be the most important predictors of anthropogenic ignition while population density and roads were generally poor predictors. Although human population has often been used as a proxy for ignitions at global scales, it is less important at regional scales when more specific land uses (e.g., agriculture) can be identified. The variability of ignition predictors among ecoregions suggests that human activities have heterogeneous impacts in altering fire regimes within different vegetation types and geographies.

Keywords: anthropogenic, fire, ignition, lightning, MCD45A1, MODIS, remote sensing, western US

\section{Introduction}

Although fire is a natural component of most ecosystems and pre-dates the evolution of hominids (Pyne, 1982; Bond \& Keely 2005; Bond et al., 2005; Bowman et al., 2009) humans are altering fire dynamics worldwide (Stephens, 2005; Korontzi et al., 2006; Archibald et al., 2009, Bowman et al., 2011). Anthropogenic changes that influence the fire cycle include changing climate (Westerling et al., 2006, Littell et al., 2009), fire suppression 
(Archibald et al., 2012) fuel alteration via the introduction of agriculture and pasture and through the introduction of non-native grasses which increase fine fuels and connectivity (D'Antonio \&Vitousek, 1992), and the addition of anthropogenic ignition sources (Cardille et al., 2001). Fire is an important regulator of ecosystems, influencing succession and vegetation assemblages at local scales and the distribution of biomes at global scales (Bond \& Keely 2005; Bond et al., 2005). Fire is also economically costly (Butry et al., 2001); the US spends over 1 billion USD per year in suppression costs alone (Abt et al., 2009). Because of these ecological and economic impacts, it is necessary to understand how humans have altered fire cycles. Here, we use a novel remote sensing approach to quantify anthropogenic impact on fire ignitions in seven western US ecoregions.

The western US is an ecologically diverse region that includes many species such as Douglas fir forest in the Pacific northwest pinyon juniper in the southwest, and ponderosa pine forest in the southwest and northern Rockies (Pyne, 1982; Keane et al., 2008; Dennison et al., 2014). Human activities are strongly altering western fire regimes. For example, increased fire frequency in forested systems in the last fifty years has been observed in the western US and has been partially attributed to rising regional temperatures and earlier spring snowmelt (Westerling et al., 2006, Dennison et al., 2014). Historical land use change also influences fire. Since the early 1900s, fire has been substantially reduced in many western US ecosystems via fire suppression (Pyne, 1982; Moore et al., 1999; Allen et al., 2002; Schoennagel et al., 2004). Suppression efforts resulted in an increase of fuels in certain ecosystems (e.g. Ponderosa pine ecosystems) as well as an initial decrease in fire occurrence (Marlon et al., 2012). Although these western US forested systems have species with adaptations to fire, altered frequency and severity of fires associated with climate and land use change can lead to different dominant species and overall changes in community composition (Keane et al., 2008). 
In addition to human impacts from climate and suppression, western US fire regimes have been impacted by the introduction of invasive plants. Non-native grasses, such as Bromus tectorum and Bromus rubens, are known to alter fire regimes by increasing fine fuels and fuel continuity (D'Antonio \&Vitousek, 1992; Balch et al., 2013; Lambert et al., 2010). As invasive grasses continue to spread and human settlement near wildland areas increases (Theobald \& Romme, 2007), ecosystems acoss western US, are increasing susceptible to fire. Humans can alter fire ignitions intentionally or through accidental fire starts. People use fire intentionally for many purposes, including for land management (e.g. agriculture and pasture maintenance), and for ecosystem management (e.g. prescribed fires) (Pyne, 1982; Bowman et al., 2011). Some of these intended fires may escape and start wildfires.

Unintended fire starts associated with people include smoking, railroad sparks, equipment use, and powerlines (The National Wildfire Coordinating Group Origin and Cause Determination Handbook, 2005). While some of these sources, such as campfire, debris burning, and arson, have obvious links to fire ignition, others are less intuitive. In the case of railroads, brake sparks and right of way track maintenance are known to cause fire ignition (Harrington \& Donnelly, 1978), while extreme winds can knock down powerlines that may ignite fires (Tse \& Fernandez-Pello, 1998).

Despite these strong relationships between humans and fire ignition, regional-scale spatial analyses of anthropogenic influences on fire ignition are lacking. Previous studies investigating the influence of humans on fire ignition have typically been at landscape scales (e.g., Vega-Garcia et al., 1995; Syphard et al., 2007; Arganaraz et al., 2015; Wu et al., 2014). Regional and global scale models of fire probability and human impact on fire have not empirically tested patterns of fire ignitions, but instead use spatial layers such as roads or human population density as proxies for human ignition pressure (Parisen et al., 2012; Hawbaker et al., 2013; Knorr et al., 2013). To date, both landscape and regional scale 
analyses assume that the importance of different anthropogenic predictors of fire ignition is constant across space, and have not tested whether human influence on fire varies between ecosystems. Anthropogenic ignitions can be controlled reasonably well by fire management, (Hawbaker et al., 2014), and therefore understanding the spatial patterns of anthropogenic fire ignitions may help with the prediction and mitigation of future fire risk.

While we know that anthropogenic ignition pressure vary globally (Pechony \& Shindell, 2009), previous studies have used only roads and population density as proxies for anthropogenic ignition when predicting fire (Yang et al., 2007; Siljander, 2008). It is unlikely that human presence alone is consistently the best predictor of fire occurrence. Thus, a better understanding of how specific human activities relate to fire ignitions would improve spatial models of fire risk.

Here, we use a novel remote sensing approach to distinguish anthropogenic fire ignitions from lightning ignitions across the western US. We then quantify the spatial relationship between anthropogenic predictors and fire ignition within seven western US ecoregions to answer the following questions: 1) What is the relative importance of anthropogenic features for predicting fire ignition in seven western US ecoregions?, and 2) How does the influence of anthropogenic features on fire ignition vary among western US ecoregions. This study presents the first regional-scale analysis of the spatial variability of human influence on fire ignitions.

\section{Methods}

Fire data

We used the Moderate Resolution Imaging Spectrometer (MODIS) Collection 5 Burned Area Product (Roy et al., 2002, 2005, 2008) to identify ignition pixels. The MODIS Burned Area Product (MCD45A1), uses a bidirectional reflectance model-based change detection algorithm (Roy et al., 2005). Burned areas are distinguished at an approximate 
$500 \mathrm{~m}$ resolution based on rapid changes in surface reflectance due to removal of vegetation, and subsequent deposition of charcoal and ash (Roy et al., 2005). Although the collection 6 MODIS Burned Area Product (MCD64A1) demonstrates superior fire detection rates, particularly for infilling fire perimeters (Giglio et al., 2009), these data were not available at the time of the analysis. The locations of potential ignition pixels associated with the two products are likely to be similar. In addition to providing a spatial location for burned areas, MCD45A1 also assigns a Julian day to each burned pixel which signifies the date of fire detection. In areas with limited cloud cover, such as the western US during summer months, MCD45A1 has higher accuracy than in areas with higher levels of cloud cover (Boshetti et al., 2010). These daily data span January 1, 2000 through December 31, 2012 (except June 2001 when there was an error in the fire detection instrument) for the eleven westernmost contiguous United States (Figure 1). We only considered fires that burned from May-October because this time frame is considered the typical fire season in the western US (Westerling et al., 2003). We retained ignitions associated with all land cover classes in the modelling analysis assuming that all ignitions have the potential to spread into wildland fires. We aimed to characterize the overall pattern of anthropogenic ignitions associated with all sources.

\section{Response Variables}

The MCD45A1 product identifies burn dates for individual ( 500 m) pixels, but does not identify unique fire perimeters. We grouped the burned pixels into unique fire perimeters based on spatial and temporal proximity. Pixels were considered part of the same fire event if they were within two days and two pixels of one another or within three days and adjacent. Temporal proximity was only considered when pixels burned in ascending order such that large fires that eventually merge would maintain unique perimeters and ignition points. In some cases where large fires burned for multiple weeks, these criteria were not appropriate. For these complex fires, we grouped pixels into a single event if burned pixels were within 
two pixels and there were no time gaps longer than three days during the entire event. After grouping all unique fire perimeters or complexes, we identified the earliest burn date. Pixels burning on the first day of multiday fires and all burned pixels in single date fires were identified as potential ignition pixels. Based on these criteria, a single fire event could have multiple potential ignition pixels. To test whether this biased our modeling results, we also averaged predictor variables (see below) for all ignition pixels in every unique fire event and repeated out analysis using only a single ignition per fire (Appendix S1).

In order to isolate ignitions likely caused by anthropogenic activity, we excluded ignitions likely to have been caused by lightning. Cloud-to-ground lightning strikes were acquired from the Vaisala National Lightning Detection Network lightning density data from 2000-2009 and the North American Precision Lightning Network from 2010-2012 to identify ignitions potentially attributable to lightning. These data included information on the location and timing of lightning strikes and have a reported median spatial accuracy of $500 \mathrm{~m}$ in the western US (Cummins \& Mur, 2009) with over 95\% of strikes having uncertainties in location of less than $4 \mathrm{~km}$ (Biagi et al., 2007). If an ignition pixel was within a 4-km radius and burned within three days after a lightning strike, it was considered a potential lightning ignition. We used a three day buffer as lightning ignitions can remain undetected by satellites for several days until weather conditions become conducive to fire spread. All other ignitions that were not spatially or temporally proximal to lightning strikes were assumed to originate from an anthropogenic source.

\section{Validation of Ignition Sources}

We used the Fire Program Analysis fire-occurrence database (FPA FOD; Short, 2015) to test the relative accuracy of the in anthropogenic vs. lightning ignition classification. The FPA FOD is a compilation of fires reported by federal, state and local agencies and encompasses the entire study period 2000-2012 (Short, 2015). The completeness and 
accuracy of these records varies by state and reporting abilities, and, while extensive, is an incomplete record of all fire activity (Short, 2014). Therefore, a lack of corresponding ignition records between FPA FOD and MCD45A1 may be due to reporting errors in FPA FOD and not necessarily attribution errors in our method (Appendix S2). Nonetheless, as the only other ignition dataset available, the comparison provides an important initial estimate of MCD45A1 ignition accuracy.

The goal of identifying lightning ignitions was to exclude them from the analysis, thus creating a clearer picture of anthropogenic ignition. In order to test our classification of lightning ignitions, we identified data points from the FPA FOD that overlapped with fire perimeters from the MCD45A1 data. The spatial and temporal accuracy of the FPA FOD dataset are unknown, and it is likely that some spatial and temporal errors exist (Short 2014). As such, we set a wide search window for overlap. Points and perimeters were considered overlapping if they were within $10 \mathrm{~km}$ spatially and burned within seven days temporally. The FPA FOD fire causes listed for each fire were then assigned to ignition points associated with that perimeter. Fires which had arson, railroad, power line, smoking, children, debris burning, structure, fireworks, campfire, equipment use, or miscellaneous listed as the cause were considered anthropogenic, while FPA FOD listed as lightning caused were considered lightning ignitions.

\section{Predictor Variables}

We chose anthropogenic features potentially associated with wildfire ignitions based on fire causes listed in the National Wildfire Coordinating Group Cause and Determination Handbook (Table 1). We used the LandFire Existing Vegetation Type 120 (LANDFIRE, 2008; Rollins, 2009) to determine presence or absence of agriculture in each 500m ignition pixel. We chose to include ignition pixels that burned on agricultural land because agricultural fires are a potentially important component of anthropogenic ignitions across the 
western US region. We used the USGS SAGEMAP Human Footprint data relating to roads, power lines, railroads, interstates, campgrounds, and population density (Leu et al., 2008). We calculated distance to roads, power lines, railroads, and interstates from the centroid of each pixel. If any of these features were present within the pixel, the distance value was set to zero. Campgrounds were treated as a binary variable denoting presence or absence in each pixel. We used the mean population density for each pixel to represent the population density for the entire pixel. Population density was log transformed to deal with outliers with large population sizes.

We used the SILVIS 2010 WUI (Wildland Urban Interface) standalone data to determine the percent of development within each pixel (Radeloff et al., 2005). Overall WUI development was calculated as the sum of high density interface, high density intermix, medium density interface, medium density intermix, low density interface, and low density intermix based on the WUICLASS10 designation.

\section{Modeling}

For each of the seven Omernik Level I Ecoregions in the western U.S. (Omernik, 1987; Figure 2), we first modeled the presence/absence of ignitions as a function of the predictor variables using generalized additive models (GAMs) in the mgcv package (Wood, 2011) in R version 3.1.2. Anthropogenic ignitions were treated as presence, while randomly selected unburned areas from 2000-2012 were treated as absence. Lightning ignitions and associated fires were excluded from analysis. We calculated the generalized variance inflation factors (GVIF) (Fox \& Monette, 1992) for predictor variables separately in each ecoregion to test for multicollinearity. We removed variables with GVIF values above 3 to avoid violations of multicollinearity. The campground predictor was removed from analysis because there were too few observations to create an effective model. The GAMs were used to explore the relationship between predictor and response variables, for variable selection 
and to identify type of relationship (e.g., linear, quadratic). Based on the predictor variables and relationships identified in the GAM analysis, we then used generalized linear models (GLMs) to identify the relative contribution of predictors within each ecoregion.If a variable was best modeled with a quadratic or cubic polynomial based on the relationship displayed in the ecoregion GAM, we kept all lower order forms (linear, or quadratic and linear, respectively) of that variable in the GLM analysis. This resulted in first, second, and third order polynomials in the construction of ecoregion GLMs. We performed backward stepwise selection for each ecoregion model until there were 12 (the maximum allowable in the hier.part package) or fewer variables and selected the GLMs with the lowest Akaike Information Criteria (AIC) value.

We tested the relative importance of each anthropogenic predictor, using hierarchical partitioning (Chevan \& Sutherland, 1991) to determine the independent model contribution for each variable included in the GLM. Hierarchical partitioning was done in R using the hier.part package (Walsh \& MacNally, 2003). To find the independent model contribution of each variable, we summed the percent model contribution of each term containing the variable. A variable with a quadratic and linear term would count as two terms in the 12 term limit. We assessed each model fit by calculating the deviance explained by the model. We tested the direction of the relationship for the top two predictors with anthropogenic ignition in each ecoregion using both a linear regression and loess smoother. We also tested the direction and strength of the relationship for the top two predictors using only anthropogenic ignitions confirmed by the FPA FOD data (Appendix S2).

\section{Results}

We identified 47,495 unique fire events in the western US from 2000-2012, with a total of 129,332 potential ignition pixels (fire events often had multiple pixels burning on the first day; Appendix S1). Of these ignition pixels, the vast majority (90\%) occurred in the 
May-October time frame and were included in this analysis (Figure 2). 26,402 ignitions $(23 \%)$ were identified as potentially caused by lightning based on the three day and four kilometer criteria, leaving a total of 90,278 ignition pixels likely attributable to anthropogenic sources. Pixels that burned exclusively on agricultural land made up a minimal $(<2 \%)$ number of ignition pixels in all ecoregions except in the Marine West Coast Forest where they made up $6.6 \%$. The total number of anthropogenic and lightning ignitions varied among ecoregions. The most anthropogenic ignitions occurred in the North American Desert and Mediterranean California ecoregions, and the fewest occurred in the Southern Semiarid Highlands and Temperate Sierra ecoregions (Table 2).

Of the 116,680 total potential ignition sources in the May-October time frame, a total of 13,170 aligned with the FPA FOD fire database when ignitions with unknown sources were excluded from analysis. This low overlap rate could reflect differences in fire size and detection likelihood. The FPA FOD fire database identifies all fires that were treated (and often extinguished) by government agencies, while MCD45A1 identifies burned area detectable within at least one $500 \mathrm{~m}$ pixel, likely including fires not reported in agency databases (e.g. agricultural fires that did not require agency response). Of the ignitions in the overlapping subset, we identified 4,093 as lightning, $83 \%$ of which were confirmed by the FPA FOD. Of the remaining ignitions, 4,372, or $48 \%$ were confirmed by the FPA FOD as anthropogenic (Table 3).

These confirmation rates match our initial goal of including all anthropogenic and potentially anthropogenic ignitions in our dataset. However, we repeated our modeling analyses (see below) using only the confirmed anthropogenic ignitions and found very similar results, suggesting that our analysis is robust to the potential inclusion of some percentage of lighting ignitions (Appendix S2).

This article is protected by copyright. All rights reserved. 
There was substantial variability in the deviance explained by each ecoregion model. The ecoregion GLMs used for hierarchical partitioning are less flexible and therefore explain less than ecoregion GAMs, however, they still perform comparably for the majority of ecoregions (Table 4). The best model GLMs based on deviance explained were in the Marine West Coast Forest (69.2\%) and North American Desert (28.6\%), whereas anthropogenic predictors only explained $5.4 \%$ of the spatial pattern of ignition in the Great Plains (Table 4). For most ecoregions, the GLMs performed similarly to the GAMs in terms of overall deviance explained, suggesting that relationships between anthropogenic predictors and ignition are reasonably well explained with linear, quadratic, or cubic functions.

After using model selection criterion, all predictor variables were retained in all ecoregion GLMs except for the Southern Semiarid Highlands and Temperate Sierras where powerlines, and powerlines/ agriculture, respectively were excluded (Table 5, Appendix S3). The polynomial term used to include predictors varied among ecoregions, but was most commonly linear or quadratic. The 12 variable maximum allowed in the hier.part package only affected the GLM created for the Great Plains ecoregion.

Model contribution from each predictor varied substantially among ecoregions. Proximity to railroads was the most consistently important predictor, with the highest or second highest model contribution in all ecoregions except for in the Great Plains and Mediterranean California. Agricultural presence had the highest model contribution in the Marine West Coast Forest (45\%) and Northwest Forested Mountains (41\%). Presence of wildland urban interface had the highest model contribution in the Southern Semiarid Highlands (39\%) and Mediterranean California (36\%). The most important predictor of anthropogenic ignition was different for the remaining three ecoregions with distance to railroad in the North American Desert (36\%), distance to road in the Temperate Sierras (57\%) and distance to interstate in the Great Plains (35\%; Figure 4). Relative contributions of 
predictor variables for models run with a single ignition per fire event were largely the same in each ecoregion (Appendix S1).

If anthropogenic features are indeed influencing fire ignitions, we expect their relationships to have a predictable directionality. For example, anthropogenic ignition should decrease with distance to roads, resulting in a negative relationship. In contrast, anthropogenic ignition should increase with higher wildland urban interface (i.e. more urban areas within wildlands), resulting in a positive relationship. This is the case for the top predictors in the regions with the highest explanatory power: Marine West Coast Forest, North American Desert, Northwest Forested Mountains, and Mediterranean California ecoregions. (Figure 5, A-D). However, the expected relationships are not evident in the regions with the lowest explanatory power (Temperate Sierras, Southern Semiarid Highlands, and Great Plains; Figure 5, E-G).

\section{Discussion}

Our analysis reveals strong spatial variability in the relationship between human land use and anthropogenic fire ignitions. This variability in anthropogenic influence suggests that humans impact ignition differently across ecoregions due to interactions with climate and land cover, and spatial variation in human land use across regions (Littell et al., 2009; Archibald et al., 2009; Marlon et al., 2012). For example, environments with wetter, larger fuels and humid weather would be less likely to carry a spark that results in ignition than those with dry, fine fuels and frequent fire weather. They would also be more fire limited as a consequence of shorter-lived fire potential through the season. In addition, human impact on the landscape varies among ecoregions (Leu et al., 2008). The results of this study underscore the complexity of the interplay between humans, climate, and fuels and their relationship with fire ignition across the western US. Given the considerable variation in the relationship 
between anthropogenic influence and fire ignitions across broad ecoregions, it is likely that the similar variance will also be evident at landscape scales.

In the Marine West Coast Forest, agricultural presence was the best predictor of anthropogenic fire with an independent model contribution of $45 \%$, suggesting that human agricultural practices in this region are strongly linked to fire ignition. While many regions contain agricultural areas, variation in crop types and agricultural burn calendars impact the patterns of agricultural influence on the landscape (Korontzi et al., 2006). For example, the Marine West Coast Forest consists largely of the Willamette Valley region, which has a long history of grass seed production beginning with rye grass and turf grass in 1935 (Conklin \& Fisher 1973). In order to prevent the spread of disease, and to remove agricultural residue which can inhibit future growth, fire is used as a regular management tool (Conklin \& Fisher 1973; Hardison 1980). It is likely that the heavy use of fire to manage these grass crop systems contributes to the high influence of agriculture on fire ignition in the Marine West Coast Forest.

Although the practice of agriculture burning is not restricted to Willamette Valley (McCarty et al., 2009), agricultural presence did not have a high model contribution in any of the remaining ecoregions except for the Northwest Forested Mountains, where post-harvest burning of wheat crops may be responsible. This may be due to the unique climate in the Marine West Coast Forest, which is one of the wettest in North America (Commission for Environmental Cooperation, 1997). In this wet area, it may be necessary to have a hotter and more intentional ignition source, such as crop residue burning, for successful ignition. However, in more arid regions, less powerful sources of ignition may be enough to ignite fuels. For example, cigarette butts require relative humidity levels below $22 \%$ for fire ignition (National Wildfire Coordinating Group, 2005), and would be more likely to start a fire in arid 
regions such as the North American Desert where distance to interstate (and associated cigarettes and automotive sparks) is an important predictor of ignitions.

Another important predictor in the North American Desert, characterized in part by a desert steppe climate (Commission for Environmental Cooperation, 1995), is distance to railroad, with a total model contribution of $39 \%$. The dry climate in this region likely encourages fire spread from railroad ignitions attributed to brake sparks and track maintenance (Harrington \& Donnelly 1978; National Wildfire Coordinating Group, 2005), whereas these sparks would be less likely to ignite larger, wetter fuel sources. Another potential reason why railroads are such a strong predictor of fire ignition in this ecoregion is because of their association with cheatgrass (Bromus tectorum), which was originally introduced in the west via railroad lines (Knapp, 1996). Cheatgrass is a fire prone invasive species (D'Antonio \& Vitousek, 1992) that has been shown to increase the fire activity in invaded areas (Balch et al., 2013). Although cheatgrass is widespread in the west, it is most dominant in the Great Basin region, covering 40,000 $\mathrm{km}^{2}$ (Bradley \& Mustard, 2005), which makes up a large portion of the North American Desert ecoregion. In this region, the distinctive combination of arid climate and fire prone fine fuels in close proximity to an ignition source likely contribute to the unique contribution of railroads to overall anthropogenic ignition in the North American Desert.

Although population density is often used as a proxy for human ignition (Cardille et al., 2001; Syphard et al., 2007; Hawbaker et al., 2014), in our western US study, it was a poor predictor. (The only notable influence was in Mediterranean California.) At global scales, spatial population density is more widely available and likely provides a reasonable proxy for other anthropogenic land use features. However, the low contribution of population density in most western US ecoregion models suggests that human use of the landscape has a greater 
impact on fire ignition than just the number of people per square kilometer. This understanding will enhance our ability to include human variables in predictive fire models.

In Mediterranean California, where population density was an important predictor of ignition, it showed a negative monotonic relationship with anthropogenic fire ignition (e.g. Figure 5d). In contrast, previous work suggests fire density is highest at intermediate levels of population density (Syphard et al., 2007; Archibald et al., 2009). An association with intermediate population densities could be due to increased levels of fire detection and suppression, as well as more fuel breaks in highly populated areas, and a lack of anthropogenic ignition sources in sparsely populated areas (Guyette et al., 2002; Syphard et al., 2007). However, fire frequency has also been found to have a negative relationship with population density regionally, for example in the Missouri Ozarks (Guyette et al., 2002), and globally (Knorr et al., 2014). Our results for the Mediterranean California ecoregion model are consistent with Guyette et al., 2002 and Knorr et al., 2014. It is likely that fires throughout the heavily populated Mediterranean California are quickly suppressed, before becoming detectable by MODIS, because they pose a threat to people and infrastructure.

Human impact (Sanderson et al., 2002) and ignition pressure (Pechony \& Shindell, 2009) are not homogenous across the globe. Therefore, how anthropogenic ignitions vary must be accounted for when predicting fires. Currently, predictive fire models typically rely on population density as a proxy for anthropogenic ignition (Yang et al., 2007; Siljander, 2008, Pecnony \& Shindell, 2009), and do not consider regional differences in ignition pressure. We suggest that regional differences in fire ignition should be taken into account when creating regional and global fire models. For example, more specific measures of human activity, such as railroads and interstates, should be tested where available, when determining the best proxy for anthropogenic ignition in fire models. However, population density is included in each ecoregion model despite its generally low overall model 
contribution. Therefore it may be used to improve predictive fire models when more specific spatial information is unavailable.

The variation in anthropogenic influence on fire ignition across ecoregions shown in this study emphasizes that human presence alone is not the best predictor of ignitions. Rather, human use of the landscape, likely combined with flammability of surrounding vegetation influences regional patterns of fire ignition. This is the first study to address how human drivers of ignition vary by ecoregion using a remote sensing approach. By better understanding how humans influence ignition, and how humans interact with regionally varying climate and fuels, we can more accurately include anthropogenic variables in predictive fire models.

\section{Acknowledgements}

This research was supported by NASA's Terrestrial Ecology Program, Grant NNX14AJ14G. We thank Kayla Baker and Anthony Accavallo for assistance with data processing. We would also like to thank two anonymous reviewers for their comments and helpful insight into this research.

This article is protected by copyright. All rights reserved. 


\section{Literature Cited}

Abt KL, Prestemon JP, Gebert KM (2009) Wildfire suppression cost forecasts for the U.S. Forest Service. Journal of Forestry, 107, 173-178

Archibald S, Staver AC, Levin SA (2012) Evolution of human-driven fire regimes in Africa. Proceedings of the National Academy of Sciences, 109, 847-852.

Archibald S, Roy DP, van Wilgen BW, Scholes RJ (2009) What limits fire? An examination of drivers of burnt area in Southern Africa. Global Change Biology, 15, 613-630.

Argañaraz JP, Gavier Pizarro G, Zak M, Landi MA., Bellis LM (2015) Human and biophysical drivers of fires in Semiarid Chaco mountains of Central Argentina. Science of the Total Environment, 520, 1-12.

Balch JK, Bradley BA, D’Antonio CM, Gómez-Dans J (2013) Introduced annual grass increases regional fire activity across the arid western USA (1980-2009). Global Change Biology, 19, 173-183.

Biagi CJ, Cummins KL, Kehoe KE, Krider EP (2007) National Lightning Detection Network (NLDN) performance in southern Arizona, Texas, and Oklahoma in 2003-2004. Journal of Geophysical Research, 112, 1-17.

Bond WJ, Keeley JE (2005) Fire as a global "herbivore": the ecology and evolution of flammable ecosystems. Trends in Ecology \& Evolution, 20, 387-94.

Bond WJ, Woodward FI, Midgley GF (2005) The global distribution of ecosystems in a world without fire. New Phytologist, 165, 525-538.

Boshetti L, Roy DP, Justice CO, Giglio L (2010) Global assessment of the temporal reporting accuracy and precision of the MODIS burned area product. International Journal of Wildland Fire, 19, 705-709.

Bowman DMJS, Balch J, Artaxo P et al. (2011) The human dimension of fire regimes on Earth. Journal of Biogeography, 38, 2223-2236. 
Bowman DMJS, Balch JK, Artaxo P et al. (2009) Fire in the Earth system. Science, 324, $481-4$.

Bradley BA, Mustard JF (2005) Identifying land cover variability distinct from land cover change: Cheatgrass in the Great Basin. Remote Sensing of Environment, 94, 204-213.

Butry DT, Mercer DE, Prestemon JP (2001) What is the price of catastrophic wildfire? Journal of Forestry, 99, 9-17.

Cardille JA, Ventura SJ, Turner MG (2001) Environmental and Social Factors Influencing Wildfires in the Upper Midwest, United States. Ecological Applications, 11, 111127.

Chevan A, Sutherland M (2011) Hierarchical Partitioning. The American Statistician, 45, 9096.

Conklin FS, Fisher DE (1973) Economic Characteristics of Farms Producing Grass Seed in Oregon's Willamette Valley. 1-86 pp.

Cummins KL, Murphy MJ (2009) An overview of lightning locating systems: History, techniques, and data uses, with an in-depth look at the U.S. NLDN. IEEE Transactions on Electromagnetic Compatibility, 51, 499-518.

D’Antonio CM, Vitousek PM (1992) Biological Invasions by Exotic Grasses, The Grass/Fire Cycle, and Global Change. Annual Review of Ecology and Systematics, 23, 63-87.

Dennison PE, Brewer SC, Arnold JD, Moritz MA (2014) Large wildfire trends in the western United States, 1984-2011. Geophysical Research Letters, 41, 799-804.

Fox J, Monette G (1992) Generalized Collinearity Diagnostics. Journal of the American Statistical Association, 87, 178-183.

Giglio L, Loboda T, Roy DP, Quayle B, Justice CO (2009) An active-fire based burned area mapping algorithm for the MODIS sensor. Remote Sensing of Environment, 113, 408- 
420.Guyette RP, Muzika RM, Dey DC (2002) Dynamics of an Anthropogenic Fire Regime. Ecosystems, 5, 472-486.

Hardison JR (1980) Role of Fire for Disease Control in Grass Seed Production. Plant Disease, 64, 641-645.

Harrington JB, Donnelly RE (1978) Fire probabilities in Ontario's boreal forest. In Proceedings of the Fifth Join Conference on Fire and Forest Meteorology. 1-4. American Meteorological Society, Boston, Massachusetts, USA.

Hawbaker TJ, Radeloff VC, Stewart SI, Hammer RB, Keuler NS, Clayton MK (2013) Human and biophysical influence on fire occurrence in the United States. Ecological Applications, 23, 565-582.

Keane RE, Agee JK, Fulé P et al. (2008) Ecological effects of large fires on US landscapes: benefit or catastrophe? International Journal of Wildland Fire, 17, 696-712.

Knapp PA (1996) Cheatgrass (Bromus tectorum L.) dominance in the Great Basin Desert: History, persistence, and influences to human activities. Global Environmental Change, 6, 37-52.

Knorr W, Kaminski T, Arneth a., Weber U (2014) Impact of human population density on fire frequency at the global scale. Biogeosciences, 11, 1085-1102.

Korontzi S, McCarty J, Loboda T, Kumar S, Justice C (2006) Global distribution of agricultural fires in croplands from 3 years of Moderate Resolution Imaging Spectroradiometer (MODIS) data. Global Biogeochemical Cycles, 20, 1-15.

Lambert AM, D’Antonio CM, Dudley TL (2010) Invasive species and fire in California ecosystems. Fremontia, 38.

LANDFIRE (2008) Existing Vegetation Type Layer. LANDFIRE 1.1.0 U.S. Department of the Interior, Geological Survey. Accessed April 2014 at http//landfire.cr.usgs.gov/viewer/ 
Leu M, Hanser SE, Knick ST (2008) The Human Footprint in the West: A Large-Scale Analysis of Anthropogenic Impacts. Ecological applications, 18, 1119-1139.

Littell JS, McKenzie D, Peterson DL, Westerling AL (2009) Climate and wildfire area burned in western U . S . ecoprovinces, 1916-2003. Ecological Applications, 19, $1003-1021$.

Marlon JR, Bartlein PJ, Carcaillet C et al. (2008) Climate and human influences on global biomass burning over the past two millennia. Nature Geoscience, 1, 697-702.

Marlon JR, Bartlein PJ, Gavin DG et al. (2012) PNAS Plus: Long-term perspective on wildfires in the western USA. Proceedings of the National Academy of Sciences, 109, E535-E543.

McCarty JL, Korontzi S, Justice CO, Loboda T (2009) The spatial and temporal distribution of crop residue burning in the contiguous United States. Science of the Total Environment, 407, 5701-5712.

Moore MM, Covington WW, Fule PZ (2013) Reference Conditions and Ecological Restoration : A Southwestern Ponderosa Pine Perspective Reference conditions and ecological restoration: A southwestern ponderosa pine perspective. Ecological Applications, 9, 1266-1277.

National Wildfire Coordinating Group (2005) Wildfire Origin \& Cause Determination Handbook.

Omernik JM (1987) Ecoregions of the conterminous United States. Annals of the Association of American Geographers, 77, 118-125

Parisien MA, Snetsinger S, Greenberg JA, Nelson CR, Schoennagel T, Dobrowski SZ, Moritz MA (2012) Spatial variability in wildfire probability across the western United States. International Journal of Wildland Fire, 21, 313-327.

This article is protected by copyright. All rights reserved. 
Pechony O, Shindell DT (2009) Fire parameterization on a global scale. Journal of Geophysical Research: Atmospheres, 114, 1-10.

Radeloff VC, Hammer RB, Stewart SI, Fried JS, Holcomb SS, Mckeefry JF (2005) The Wildland - Urban Interface in the United States. Ecological Applications, 15, 799805.

Rollins MG (2009) LANDFIRE : a nationally consistent vegetation, wildland fire, and fuel assessment. International Journal of Wildland Fire 18, 235-249.

Roy DP, Boschetti L, Justice CO, Ju J (2008) The collection 5 MODIS burned area product — Global evaluation by comparison with the MODIS active fire product. Remote Sensing of Environment, 112, 3690-3707.

Roy DP, Jin Y, Lewis PE, Justice CO (2005) Prototyping a global algorithm for systematic fire-affected area mapping using MODIS time series data. Remote Sensing of the Environment, 97, 137-162.

Roy DP, Lewis PE, Justice CO (2002). Burned area mapping using multi-temporal moderate spatial resolution data-A bi-directional reflectance model-based expectation approach. Remote Sensing of Environment, 83, 263-286.

Sanderson EW, Jaiteh M, Levy MA, Redford KH, Wannebo A V., Woolmer G (2002) The Human Footprint and the Last of the Wild. BioScience, 52, 891-904.

Schoennagel T, Veblen TT, Romme WH (2004) The Interaction of Fire, Fuels, and Climate across Rocky Mountain Forests. BioScience, 54, 661-676.

Short, KC (2014) Spatial wildfire occurrence data for the United States, 1992-2013. Earth System Science Data.6, 1-27.

Short, KC (2015) Spatial wildfire occurrence data for the United States, 19922013[FPA_FOD_20130422]. Fort Collins, CO: USDA Forest Service, Rocky Mountain Research Station. http://dx.doi.org/10.2737/RDS-2013-0009

This article is protected by copyright. All rights reserved. 
Siljander M (2009) Predictive fire occurrence modelling to improve burned area estimation at a regional scale: A case study in East Caprivi, Namibia. International Journal of Applied Earth Observation and Geoinformation, 11, 380-393.

Stephens SL (2005) Forest fire causes and extent on United States Forest Service lands. International Journal of Wildland Fire, 14, 213-222.

Syphard AD, Radeloff VC, Keeley JE, Hawbaker TJ, Clayton MK, Stewart SI, Hammer RB (2007) Human influence on California fire regimes. Ecological Applications, 17, $1388-1402$.

Theobald DM, Romme WH (2007) Expansion of the US wildland-urban interface. Landscape and Urban Planning, 83, 340-354.

Tse SD, Fernandez-Pello AC (1998) On the flight paths of metal particles and embers generated by power lines in high winds-a potential source of wildland fires. Fire Safety Journal, 30, 333-356.

Vega-Garcia C, Woodard PM, Titus SJ, Adamowicz WL, Lee BS (1995) A Logit Model for Predicting the Daily Occurrence of Human Caused Forest-Fires. International Journal of Wildland Fire, 5, 101-111.

Walsh C, MacNally R (2003) Hierarchical partitioning. R project for statistical computing.

Westerling A, Gershunov A, Brown TJ, Cayan DR, Dettinger M. (2003) Climate and wildfire in the western United States. Bulletin of the American Meteorological Society, 84, 595604.

Westerling AL, Hidalgo HG, Cayan DR, Swetnam TW (2006) Warming and Earlier Spring Increase Western U.S. Forest Wildfire Activity. Science, 313, 940-943.

Wood SN (2011) Fast stable restricted maximum likelihood and marginal likelihood estimation of semiparametric generalized linear models. Journal of the Royal Statistical Society, Series B (Statistical Methodology), 73, 3-36.

This article is protected by copyright. All rights reserved. 
Wu Z, He HS, Yang J, Liu Z, Liang Y (2014) Relative effects of climatic and local factors on fire occurrence in boreal forest landscapes of northeastern China. Science of the Total Environment, 493, 472-480.

Yang J, He HS, Shifley SR, Gustafson EJ (2007) Spatial Patterns of Modern Period HumanCaused Fire Occurrence in the Missouri Ozark Highlands. Forest Science, 53, 1-15.

Data Availability

Data associated with this paper have been deposited in ScholarWorks@UMassAmherst.

Anthropogenic ignitions data: http://dx.doi.org/10.7275/R56W9803

Ignition cause data: http://dx.doi.org/10.7275/R5348H8P

Table 1: Predictor data layers used in this analysis are associated with one or more of the wildfire causes listed in the National Wildfire Coordinating Group Origin and Cause Determination Handbook.

\begin{tabular}{|l|l|l|}
\hline Data Layer & Data Source & $\begin{array}{l}\text { National Wildfire Coordinating } \\
\text { Group Ignition Cause Category }\end{array}$ \\
\hline Lightning & Vaisala NLDN & Lightning \\
\hline Roads/ Interstates & SAGEMAP (Leu et. al., 2008) & Smoking, Arson, Equipment Use \\
\hline Powerlines & SAGEMAP (Leu et. al., 2008) & Powerlines \\
\hline Railroads & SAGEMAP (Leu et. al., 2008) & Railroads, Arson, Equipment Use \\
\hline Campgrounds & SAGEMAP (Leu et. al., 2008) & Campfire \\
\hline $\begin{array}{l}\text { Wildland urban interface/ } \\
\text { Population }\end{array}$ & $\begin{array}{l}\text { SILVIS/ SAGEMAP (Radeloff } \\
\text { et al.,2005; Leu et al, 2008) }\end{array}$ & $\begin{array}{l}\text { Smoking, Arson, Children, Fireworks, } \\
\text { Cutting, Welding }\end{array}$ \\
\hline Vegetation Type & LANDFIRE & Agriculture \\
\hline
\end{tabular}

This article is protected by copyright. All rights reserved. 
Table 2: The total number of lightning and anthropogenic ignitions in each of the seven western US ecoregions. Ignitions not analyzed occurred outside of the May-October window of each year.

\begin{tabular}{|l|r|r|r|r|}
\hline Ecoregion & Lightning & Anthropogenic & $\begin{array}{l}\text { Total } \\
\text { Ignitions }\end{array}$ & $\begin{array}{l}\text { Anthropogenic } \\
\text { Ignitions/km2 }\end{array}$ \\
\hline Great Plains & $36 \%$ & $64 \%$ & 9283 & 0.01 \\
\hline Marine West Coast Forest & $17 \%$ & $83 \%$ & 10620 & 0.11 \\
\hline Mediterranean California & $7 \%$ & $93 \%$ & 18582 & 0.10 \\
\hline North American Desert & $26 \%$ & $74 \%$ & 60660 & 0.03 \\
\hline Northwestern Forested Mountain & $20 \%$ & $80 \%$ & 14977 & 0.01 \\
\hline Southern Semiarid Highlands & $20 \%$ & $80 \%$ & 776 & 0.01 \\
\hline Temperate Sierras & $42 \%$ & $58 \%$ & 1782 & 0.01 \\
\hline All Ecoregions & $23 \%$ & $77 \%$ & 116680 & 0.03 \\
\hline Ignitions Not Analyzed & & & 12652 & \\
\hline
\end{tabular}

Table 3: MODIS Burned Area Product (MCD445A1) ignitions that overlapped with the Fire Program Analysis fire occurrence database (FPA FOD) data set were used to validate attribution of lightning as an ignition source. Using our method, we correctly identified $81 \%$ of our lightning ignitions that corresponded to a fire in the FPA FOD data set.

\begin{tabular}{|c|c|c|c|c|}
\hline \multirow{4}{*}{$\begin{array}{l}\text { FPA } \\
\text { FOD }\end{array}$} & \multicolumn{3}{|c|}{ MCD45A1 } \\
\cline { 2 - 5 } & Anthropogenic & Anthropogenic & Lightning & 5075 \\
\cline { 2 - 5 } & Lightning & 4372 & 703 & 8095 \\
\cline { 2 - 5 } & & 9705 & 4390 & $\begin{array}{c}\text { 13170 Total } \\
\text { Overlap }\end{array}$ \\
\cline { 2 - 5 } & & $\begin{array}{c}48 \% \text { confirmed } \\
\text { anthropogenic }\end{array}$ & $83 \%$ confirmed lightning & \\
\hline
\end{tabular}

This article is protected by copyright. All rights reserved. 
Table 4: The deviance explained by the best generalized linear model (GLM) varied by ecoregion but was comparable to the deviance explained by the general additive model (GAM) with the same variables for each region.

\begin{tabular}{|l|r|r|}
\hline Ecoregion & $\begin{array}{l}\text { Deviance } \\
\text { Explained (GLM) }\end{array}$ & $\begin{array}{l}\text { Deviance } \\
\text { Explained (GAM) }\end{array}$ \\
\hline Marine West Coast Forest & $69.2 \%$ & $74.0 \%$ \\
\hline North American Desert & $28.6 \%$ & $30.2 \%$ \\
\hline Northwest Forested Mountains & $17.0 \%$ & $20.1 \%$ \\
\hline Mediterranean California & $15.8 \%$ & $18.5 \%$ \\
\hline Temperate Sierras & $8.2 \%$ & $16.7 \%$ \\
\hline Southern Semiarid Highlands & $8.2 \%$ & $10.5 \%$ \\
\hline Great Plains & $5.4 \%$ & $6.8 \%$ \\
\hline
\end{tabular}

This article is protected by copyright. All rights reserved. 
Table 5: After testing for multicollinearity, the remaining predictor variables were used to create ecoregion GLMs. The number in the table indicates the order of polynomial used for each predictor in each ecoregion, which ranged from first to third order.

\begin{tabular}{|c|c|c|c|c|c|c|c|}
\hline & \multicolumn{7}{|c|}{ Predictor Variables Modeled by Ecoregion } \\
\hline Ecoregion & Road & Interstate & Powerline & Railroad & WUI & Log Pop & Agriculture \\
\hline $\begin{array}{c}\text { Southern Semiarid } \\
\text { Highlands }\end{array}$ & 2 & 1 & & 1 & 1 & 1 & 1 \\
\hline Temperate Sierras & 3 & 2 & & 3 & 1 & 1 & \\
\hline $\begin{array}{c}\text { Mediterranean } \\
\text { California }\end{array}$ & 2 & 2 & 2 & 2 & 1 & 2 & 1 \\
\hline $\begin{array}{c}\text { Marine West Coast } \\
\text { Forest }\end{array}$ & 1 & 2 & 2 & 1 & 1 & 2 & 1 \\
\hline $\begin{array}{c}\text { Northwest Forested } \\
\text { Mountains }\end{array}$ & 2 & 2 & 2 & 3 & 1 & 1 & 1 \\
\hline Great Plains & 2 & 3 & 2 & 1 & 1 & 2 & 1 \\
\hline $\begin{array}{c}\text { North American } \\
\text { Desert }\end{array}$ & 1 & 2 & 1 & 3 & 1 & 2 & 1 \\
\hline
\end{tabular}

Figure 1: The study area is composed of the eleven westernmost contiguous US states. Burned (a) and ignition (b) pixels were determined using the MODIS Burned Area Product (MCD45A1).

Figure 2: Fire ignitions are distributed throughout the western US. For all ignitions that occurred from May-October 2000-2012, we determined whether the ignition had an anthropogenic (a) or lightning (b) source using data from Vaisala National Lightning Detection Network. The distribution of anthropogenic ignitions varied between ecoregions (c). The ecoregions are abbreviated as follows: MWF $=$ Marine West Coast Forest, NAD= North American Desert, MC= Mediterranean California, TS= Temperate Sierras, SSHSouthern Semiarid Highlands, GP= Great Plains, NFM= Northwest Forested Mountains.

Figure 3: The percent of MODIS (MCD45A1) lightning ignitions that were confirmed by the Fire Program Analysis fire occurrence database FPA FOD data varied among ecoregions, but 
averaged $83 \%$. The average number of confirmed anthropogenic ignitions per region was $48 \%$. We correctly identified lightning ignitions above a rate of $75 \%$ for five out of the seven ecoregions, with the lowest accuracy in the Marine West Coast Forest and Mediterranean California.

Figure 4: The top anthropogenic predictors of anthropogenic ignition varied widely between ecoregions. Pie charts show the independent model contribution of each predictor variable for the best ecoregion model. *Negative values show that the variable acts as a suppressor of other model variables, meaning that it is not a great predictor itself, but suppresses the residual error of the model.

Figure 5: The relationship of the two best model predictors and anthropogenic ignition are shown for each ecoregion. These relationships are in the expected direction in the four ecoregions with the highest explanatory power (a-d), but are counter intuitive in the three ecoregions with poor explanatory power (e-g). The black line denotes a linear relationship, while the gray line shows the loess smoother.

This article is protected by copyright. All rights reserved. 
(a)

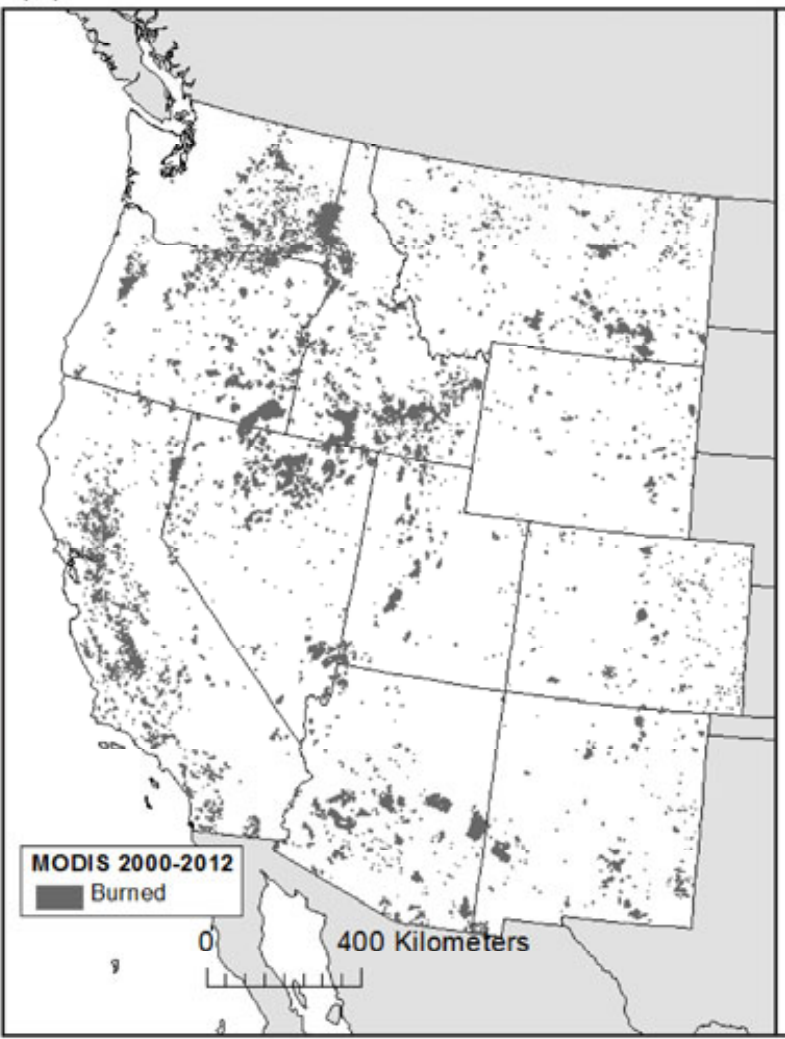

(b)

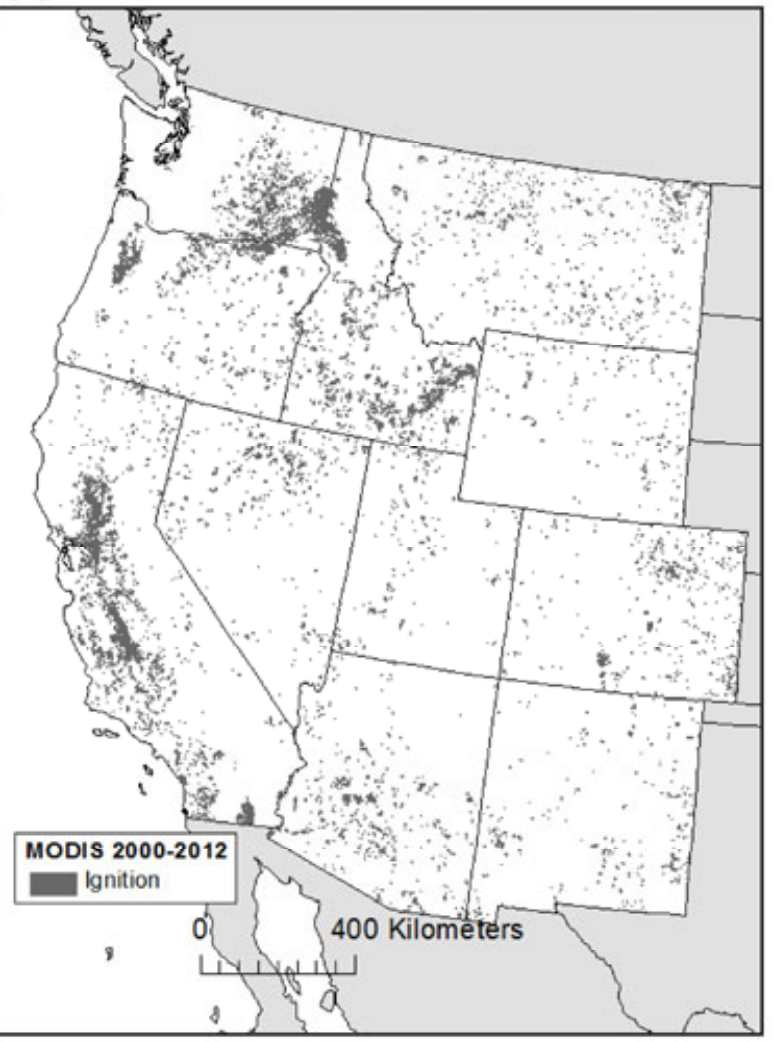

(a)

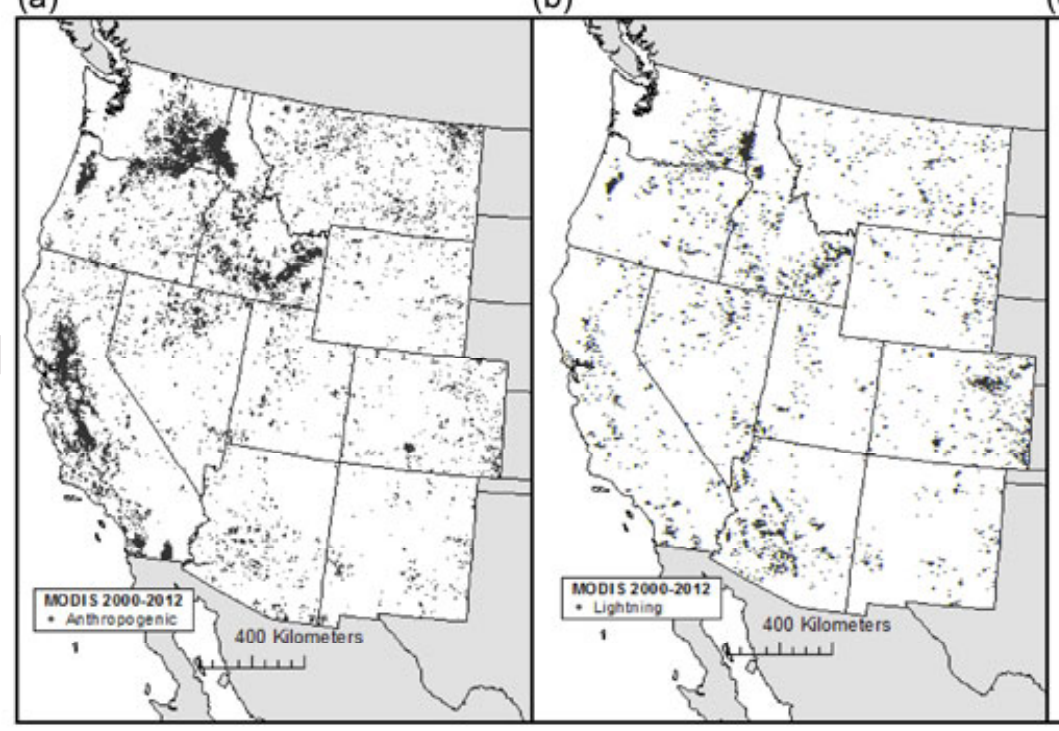

(c)

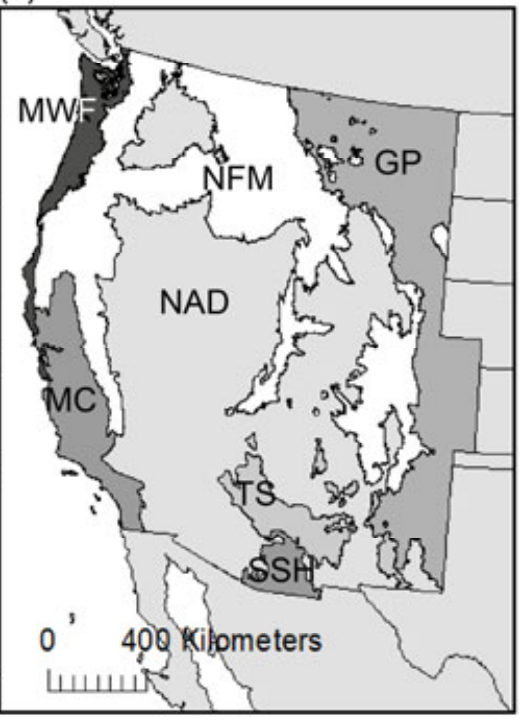

This article is protected by copyright. All rights reserved. 
MCD45A1 and FPA FOD Fire Attribution Comparison

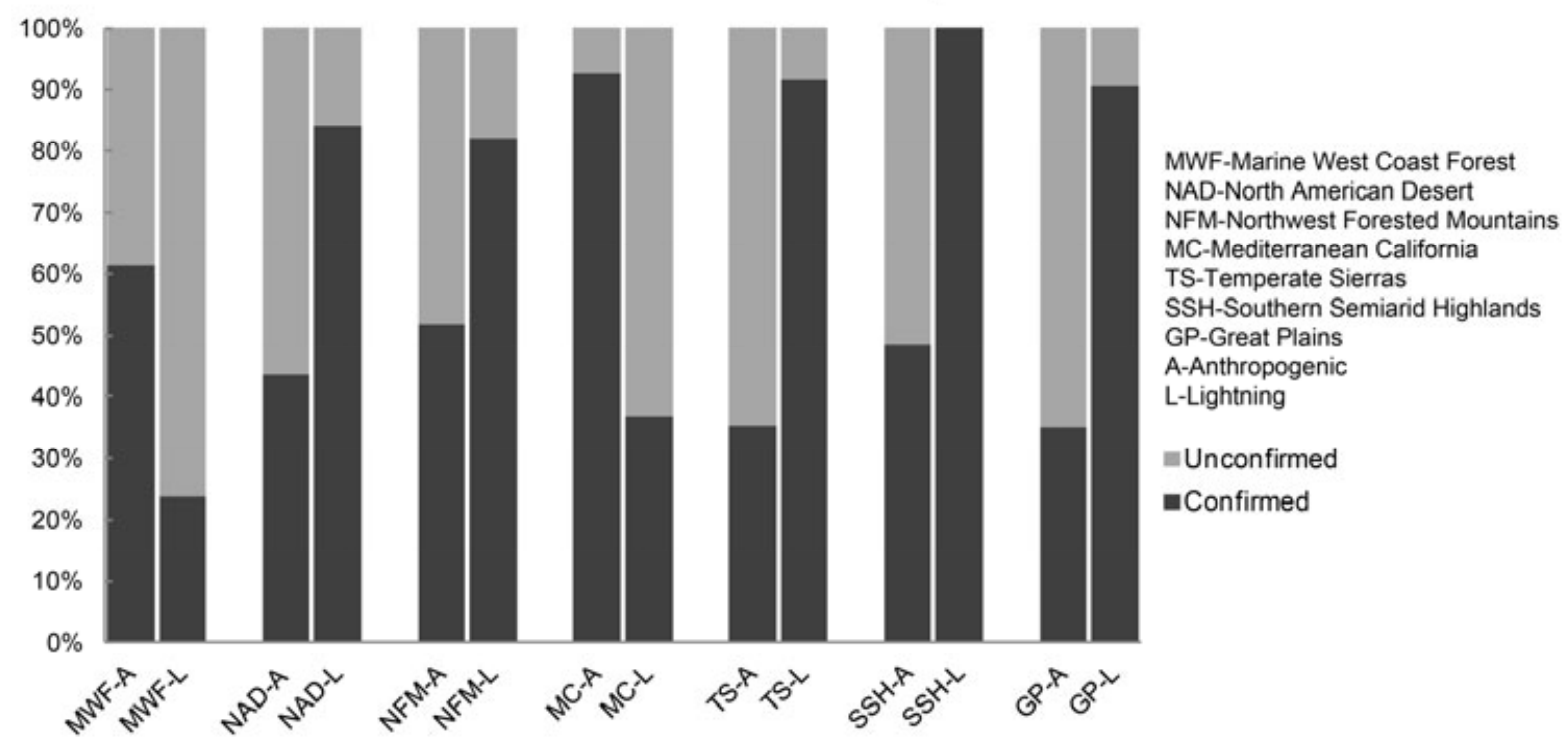

This article is protected by copyright. All rights reserved. 


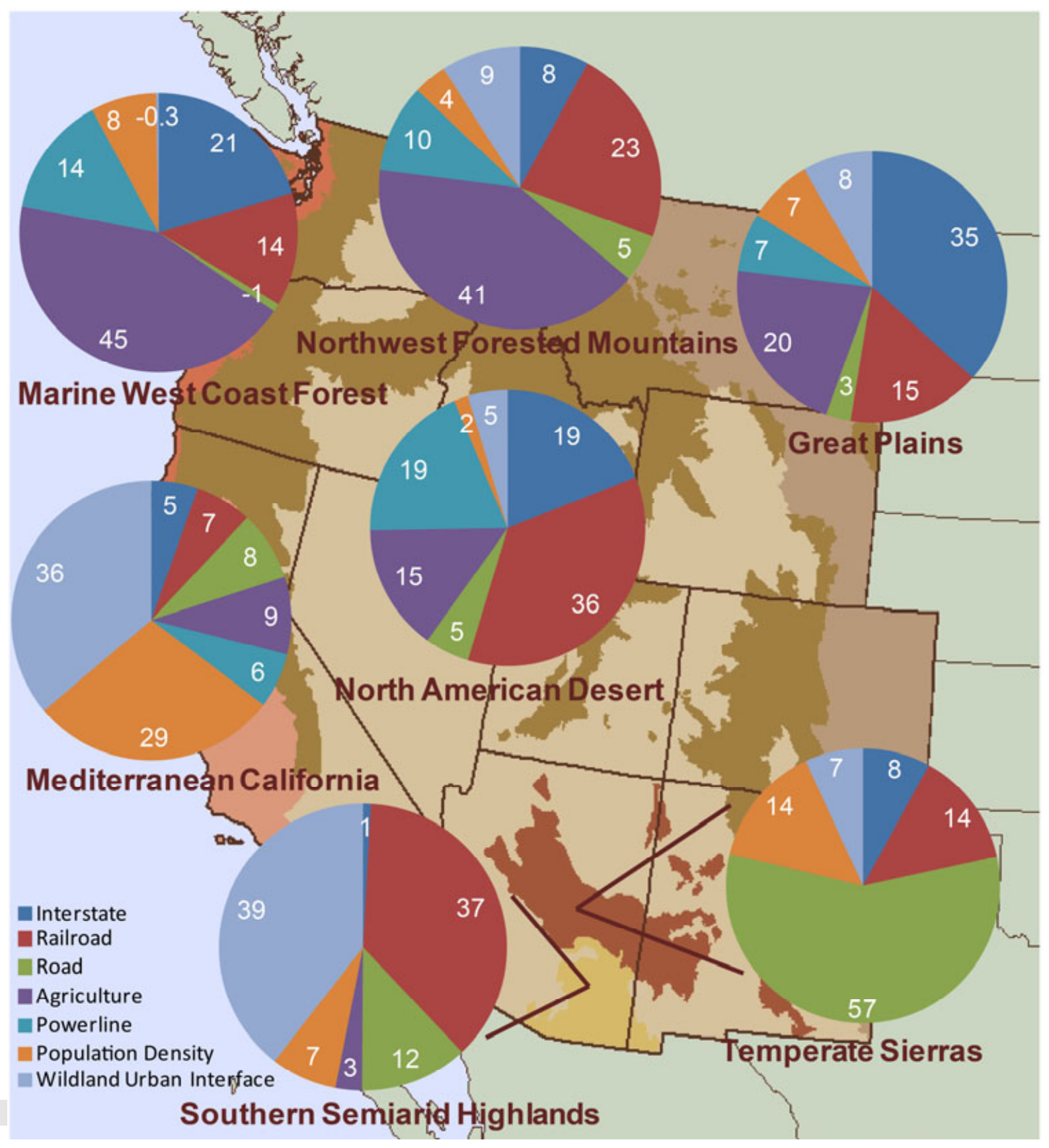

This article is protected by copyright. All rights reserved. 
(a)

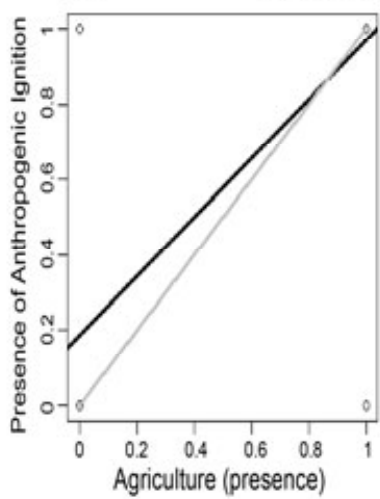

(c)

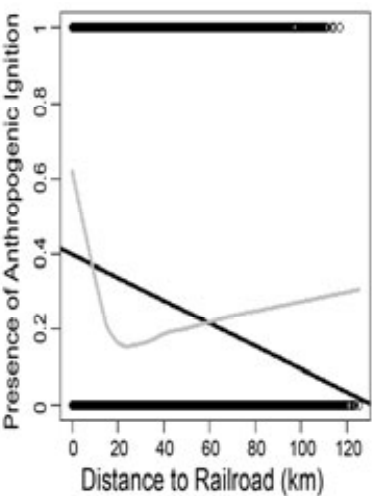

(b)

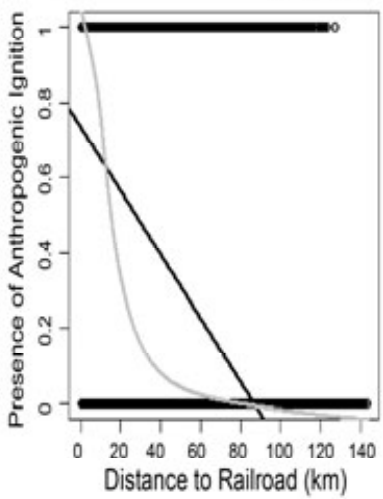

North American Desert

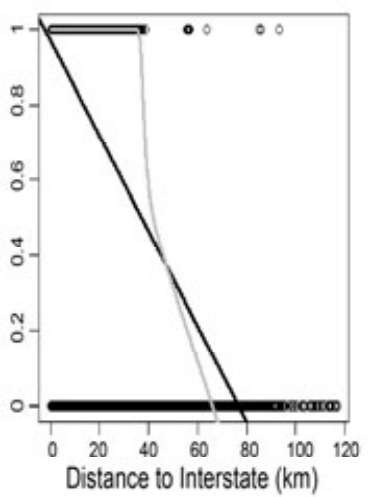

(d)
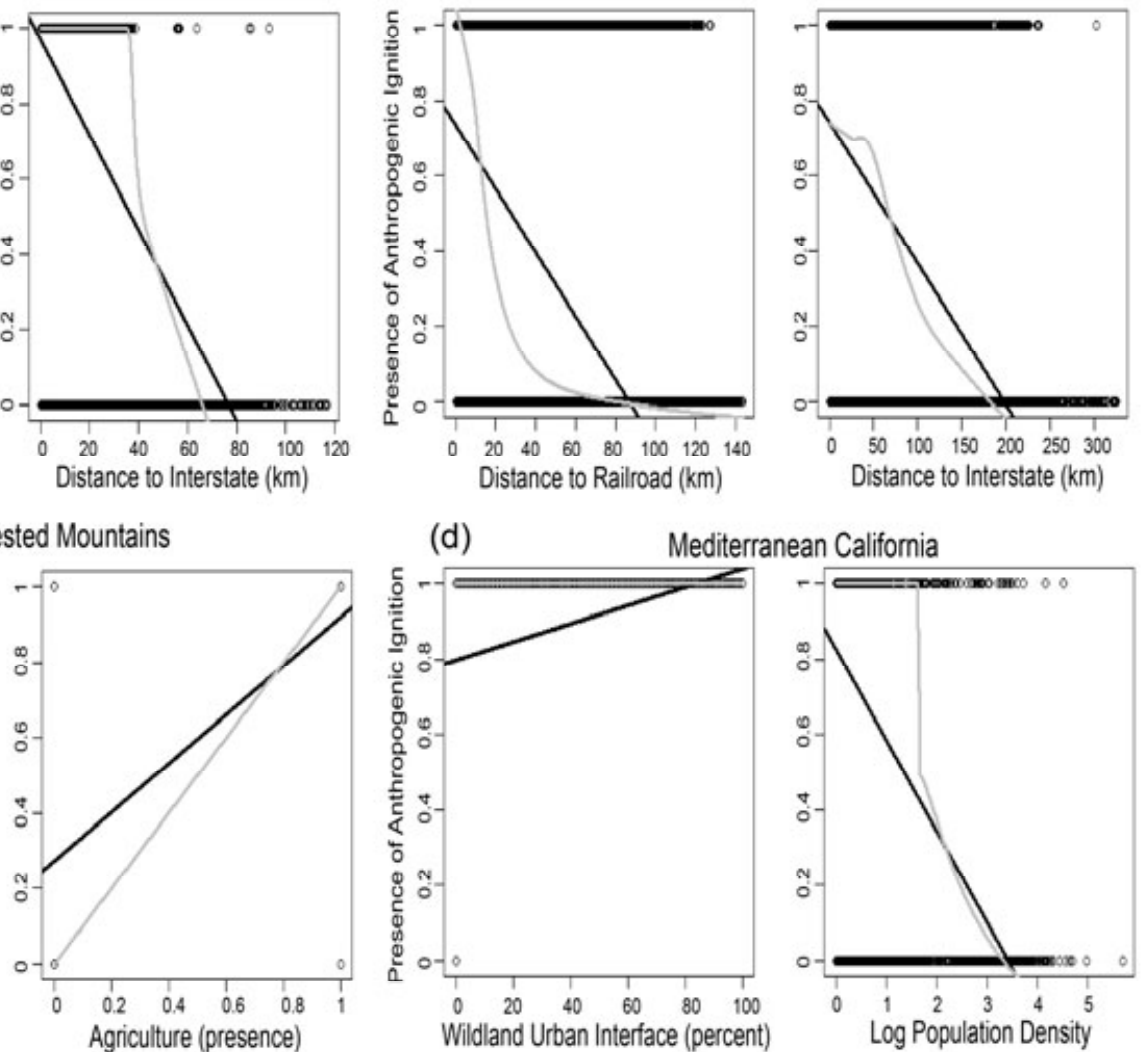

(e)

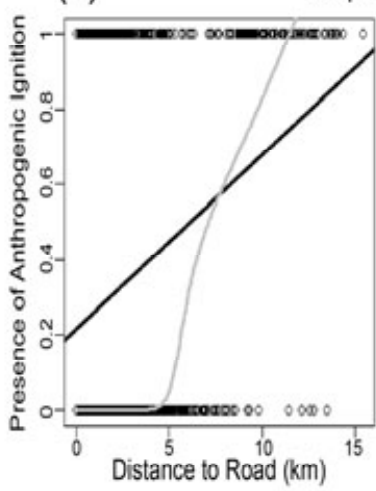

Temperate Sierras

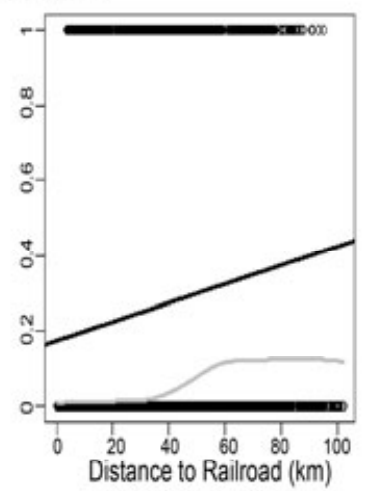

(g)

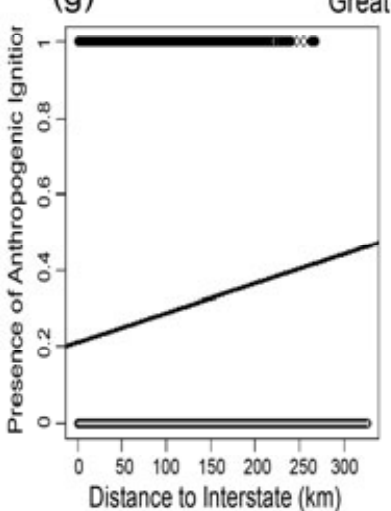

Great Plains

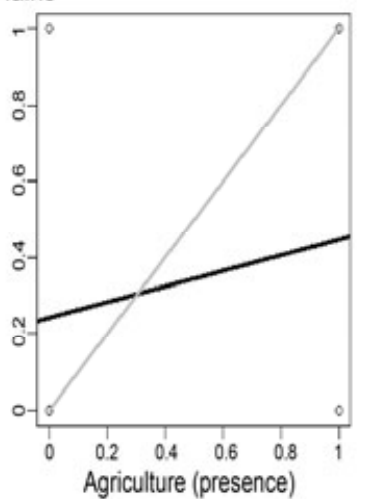

(f) Southern Semiarid Highlands
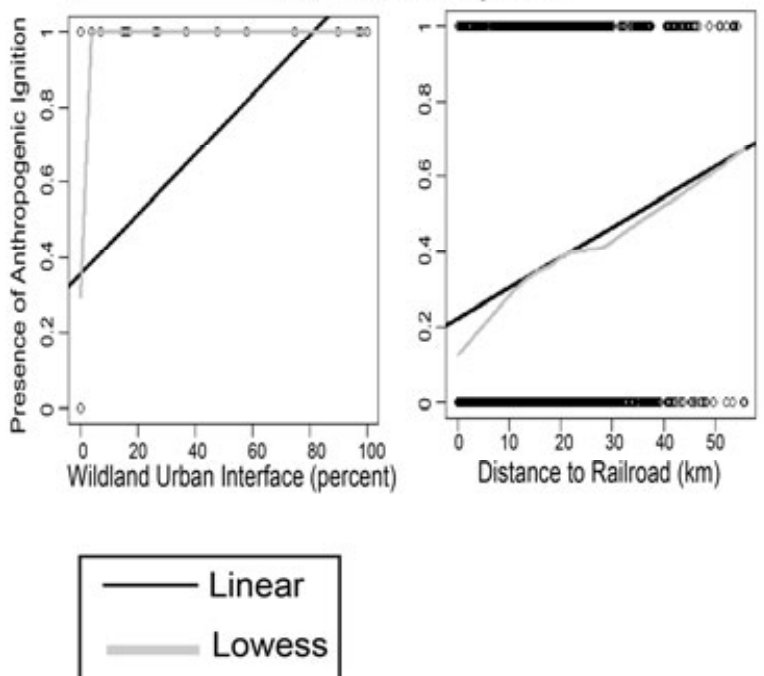

This article is protected by copyright. All rights reserved. 